ARTICLE HISTORY: Received: October 05, 2021 Accepted: November 27, 2021 Published: December 04, 2021

\title{
LABOR MARKET PROBLEMS IN UZBEKISTAN IN THE CONTEXT OF COVID-19 PANDEMIA
}

\author{
Axunova Ogulxan Ergashovna, \\ Nematova Shaxlo Egamgamberdievna \\ Department of Economics and Service, \\ Fergana State University, Uzbekistan
}

\begin{abstract}
Abstarct. The article discusses general issues of the development of the labor market in Uzbekistan in the context of the Covid-19 coronavirus pandemic. In the course of the presentation, the ongoing reforms on the generalization and structuring of the main elements of the international and national labor market associated with the human capital index are investigated, its functions are systematized, the factors of its evolutionary development are classified, as well as the role of the labor market in the formation of a platform for sustainable development of the economy and the national economies that form it.

Keywords: labor market, employment contract, human capital index, telework, telecommuting, migration, health, jobs.
\end{abstract}

On March 11, 2020, the World Health Organization declared the coronavirus condition a pandemic. The new Covid-19 coronavirus infection of the virus, which started in late December 2019 in Wuhan, China, and then spread around the world, had a great impact on the social life and economy of countries around the world. The pandemic and related restrictive measures have led to a sharp decline in consumption and investment and have led to major changes in the labor market. The loss of working time in the second quarter of 2020 alone led to the loss of nearly 500 million permanent jobs (ILO 2020).

PF of the President of the Republic of Uzbekistan dated March 19, 2020 In accordance with the Decree No. 5969 "On priority measures to mitigate the negative impact of the coronavirus pandemic and the global crisis on sectors of the economy", sponsors) is prohibited from terminating employment contracts with existing employees at the initiative of the employer. That is, it is clear from this norm that the parents of a child under 14 years of age infected or quarantined with a coronavirus infection Employers of employees whose mothers (substitutes, guardians, trustees) even in the case of dismissal. Order of the Minister of Employment and Labor Relations of the Republic of Uzbekistan dated March 25, 2020 "On approval of the Regulation on temporary transfer of employees to remote work, flexible work schedule or home work during the quarantine period" method, flexible work schedule or temporary procedure for transfer to work at home". This regulation is a measure to prevent the spread of coronavirus infection. established a temporary procedure for the transfer of all employees of the organization, regardless of the form of government and ownership, to work remotely, on a flexible work schedule or at home during the implementation of activities.

Non-standard forms of labor use (hired labor, outsourcing, outstaffing, freelancing), which are widely practiced in developed countries, are also entering our country. This is due to the flexibility of the labor market, which allows employers to modernize and diversify production in an innovative economy.

Innovative development of the economy is creating new forms of labor relations. Production based on high technology (computerization, 3D technology, robotics, virtual communication) is forming a new, non-standard system of labor relations, in addition to traditional labor relations. Non-standard forms of labor use (hired labor, outsourcing, outstaffing, freelancing), which are widely practiced in developed countries, are also entering our country. This is due to the flexibility of the labor market, which allows employers to modernize and diversify production in an innovative economy.

Economist academician K. Abdurahmanov also recognized "telework or telecommuting" as non-standard forms of labor relations. According to the scientist, if traditional labor relations are institutionalized, ie have a legal basis, their new ones are not legally formalized and have not yet become a common practice. Therefore, they are also called nonstandard labor relations [3].

Economist DA Nasimov in his research aims to prevent unsustainable employment from leading to social vulnerability in society. the number of people employed in the formal and informal sectors of the economy, the number of people employed in the informal sector of the economy, the volume of investments in fixed assets in the economy, the share of people who went abroad to work, recommended the use of a tiered model in forecasting the minimum wage in the country [10]. According to Asamkhodjaeva, the use of human capital increases not only the income of employees, but also the income of enterprises and the state.

The main types of person-centered investments are education, training, health, migration, labor market information, childbirth and upbringing. Education and training increase the volume of human capital, health care prolongs its service life, the search for information in the migration and labor market will increase the cost of its services, the birth and upbringing of children will increase the next generation. However, in a short, practical sense, investing in human capital 
is often understood as the cost of education and production training, as they are a special type of activity for the formation of knowledge, skills and competencies [12].

According to H. Koller, the pandemic was not only a crisis in the health sector, but also a profound blow to the world economy and society. This situation threatens to alienate the world community from the achievements of sustainable development goals in achieving decent work and other goals. At the same time, the crisis requires comprehensive, coordinated and effective multilateral measures.

Heinz Koller is both in the normal period of government and in times of crisis He praised Uzbekistan's efforts to ensure decent working conditions, noting that "Uzbekistan has demonstrated political commitment and leadership." According to him, the most pressing problems of the national labor market in the country are the support of vulnerable groups. special attention is paid to the formation of renewed directions of support, social dialogue and international cooperation [7].

According to Norov, the largest number of working hours was reduced in Arab countries (8.1\%). This means that 5 million people will be unemployed. In terms of unemployment, the second place is occupied by Europe (7.8\%, or 12 million people) and the third place is occupied by the Asia-Pacific region (7.2\%, or 12.5 million people).

Analysts at the International Labor Organization warn that there is a risk of job cuts or reduced working hours in areas where another 1,250 million people are employed. The hotel business, services and wholesale and retail sectors, as well as education, healthcare, utilities, agriculture, public services and public safety, also suffer the least. The risk of the construction, financial and insurance services labor market pandemic suffering is moderate. The risk of damage to the labor market in the fields of arts and entertainment, transport services, hotel and tourism business, real estate, industrial production, wholesale and retail trade, car repair services is above average.

It is also possible that more than 1.5 billion people worldwide could be left without a livelihood. This category is expected to include employees in the manufacturing and food industries. The coronavirus pandemic is hitting the global labor market hard, especially the informal sector. The first month of the crisis led to a 60 percent reduction in informal workers worldwide.

In Russia, home to a large proportion of Uzbek labor migrants in recent years, special attention should be paid to the impact of the pandemic on the economy and the prospects for the labor market. M. According to Kholmukhamedov, according to the results of monitoring published by the International Labor Organization in the 1st quarter of 2020, the Covid-19 pandemic in early April led to the complete or partial closure of 2.7 billion jobs worldwide, which affected the world's working population. Affected $81 \%$.

There is a risk that the number of poor people in the world will almost double, or 500 million people. According to the World Bank, due to the economic crisis caused by the Covid-19 pandemic and the quarantine measures applied, the total volume of remittances will fall sharply by $20 \%$. Given the number of migrant workers in Uzbekistan, this figure is more than 500,000 people likely to be unable to find permanent jobs due to the coronavirus pandemic [9].

As a result of restrictions on the movement of people in our country to combat coronavirus infection, enterprises have been forced to suspend their activities in whole or in part. As a result, the interests of self-employed workers working in various sectors of the economy have been seriously undermined. In most cases, the employment rate in the informal sector is higher in rural areas, which can be seen when analyzing by regions. According to statistics, the head of state Sh. At a meeting held by Mirziyoyev on April 22, 2021, it was noted that due to quarantine in the country, the volume of production and services at 196 thousand enterprises has sharply decreased [5].

When we analyze the numbers on a global scale, we see that the situation is much more serious. The International Labor Organization (ILO) estimates that in the second quarter of 2020, 195 million full-time workers lost their jobs. As a result, it is estimated that by the end of 2020 , the amount of wages lost by workers around the world will be $\$ 3.4$ trillion.

With the support of the International Labor Organization, Uzbekistan has carried out extensive work on the formation of the National Employment Strategy, which is an important strategic document for the labor market until 2030. The Public Works Fund has allocated 450 billion soums (\$25 million) to expand the coverage and direction of temporary employment services. During the three months of the pandemic, about 230,000 unemployed people were employed at the expense of the Public Works Fund.

A mechanism to subsidize low-income families for housing construction and the establishment of agricultural cooperatives has been developed, as a result of which more than 40,000 families have been provided with income. 3,000 unemployed people were provided with additional subsidies for the development of entrepreneurship. The procedure for receiving unemployment benefits has been simplified. According to the new procedure, about 20,000 unemployed people received unemployment benefits. In total, as a result of coordinated work over three months, the ministry has provided employment and permanent income to 374,000 citizens.

Also on the protection of workers in the workplace during a pandemic measures were taken and systematic monitoring of sanitary norms and occupational safety at enterprises was organized. Monitoring teams of labor inspectors visited 5,757 enterprises. A separate Callcenter has been set up with the 1176 hotline. The State Labor Inspectorate considered 8.2 thousand complaints of citizens on violations of labor laws and discrimination in the workplace, 
including 3,000 complaints from women. According to the results of the inspections, the labor rights of 3,600 citizens, including 1,200 women, have been restored.

Given the urgent need to transfer workers to a "remote" mode of work in the event of a pandemic, the ministry has introduced a "Regulation on the temporary procedure for the transfer of workers to remote work." Pregnant women, the elderly and people with disabilities, and people with chronic illnesses were given priority in exercising their right to work remotely.

Also, according to the official statement of the Ministry of Employment and Labor Relations of the Republic of Uzbekistan, the anti-crisis measures taken by Uzbekistan fully comply with the four main principles of the International Labor Organization to combat the pandemic. These are:

1) stimulating the economy and employment; 2) support of enterprises, jobs and income; 3) protection of workers in the workplace; 4) social communication [7].

According to the standards of the International Labor Organization, the main principles of staff retention during the Covid-19 pandemic are as follows: [11]:

1. Stimulation of the economy and employment, including:

- active fiscal policy;

- monetary policy;

- lending and financial support to specific sectors, including health care.

2. Business, Workplace and Income Support:

- coverage of everyone with social protection;

- taking measures to maintain employment;

- providing tax and financial benefits to enterprises.

3. Protection of workers in the workplace:

- adaptation of workers to the new labor standards, including the transfer to remote work;

- universal coverage with medical services;

- Increasing the amount of paid leave.

The results of the above study show that in the context of the Covid-19 pandemic, Uzbekistan has implemented targeted reforms to address pressing issues of the labor market. This, in turn, in the context of the Covid-19 pandemic requires the introduction of appropriate changes in the regulations governing the current problems of the labor market in Uzbekistan, based on the real situation. This will lead to the optimization of the state's expenditures on the labor market in the social sphere in connection with the stabilization of the labor market in Uzbekistan in the context of the Covid-19 pandemic.

Based on the above, we note the following suggestions: the pandemic showed that there are a number of problems in the development of sustainable international relations and the lack of a global strategic action plan in emergencies, in particular:

first, restrictive measures should be taken only temporarily, with mandatory compliance with the rights and freedoms of citizens. Such measures support international trade, especially in medical products, as well as those in need of social protection. must be commensurate with the risks of not obstructing support;

second, the rapid spread of the pandemic has highlighted the need for systematic, timely, and effective preventive measures, while preventing overcrowding in the health sector at the time the pandemic was declared. Preventive measures include, in the first instance, forecasting, early detection of outbreaks, measures to combat the epidemic, and mitigation of its consequences; third, the pandemic demonstrated the importance of occupational safety.

\section{List of used literature:}

1. Decree of the President of the Republic of Uzbekistan "On priority measures to mitigate the negative impact of the coronavirus pandemic and the global crisis on sectors of the economy" (No. PF-5969 of March 19, 2020).

2. Regulation "On the temporary procedure for the transfer of employees to work remotely, on a flexible work schedule or at home during the implementation of quarantine measures." (Order of the Minister of Employment and Labor Relations of the Republic of Uzbekistan dated March 25, 2020 No. 9-2020 / B).

3. Abdurahmanov Q. Labor Economics: Theory and Practice / Textbook. -T.: FAN, 2019. 314-316 b.

4. COVID-19 in Central Asia: Implications and Policy Responses. https://www.oecd.org/eurasia/competitivenessprogramme/central-asia/COVID-19-crisisresponse-in-Central-Asia-Russian.pdf

5. The impact of the pandemic on global labor relations. The official website of the International Labor Organization is http://ilo.org. Date of application: 08.05.2020.

6. The issue of employment was discussed. Official website of the President of the Republic of Uzbekistan http://president.uz. Requested date: 08.05.2020.

7. Sustainable Development Goals and Sustainable Social Development: A New Experience of Interaction. https://mehnat.uz/uz/news/stable-developmentalgoals-and-a-new-experience-of-sustainable-social-developmentinteraction-cooperation. 
8. Norov O. What is the situation in the world labor market in the context of a pandemic, how much Is a person unemployed? https: //uza.uz/oz/society/pandemiya-sharoitida-dunye-me-nat-bozori-davaziyat-anday-an-11-06-2020

9. Kholmukhamedov M. Social support in the context of a pandemic crisis support directions.https: //review.uz/en/post/pandemic-crisis- conditions-population-social-support-orientations.

10. Nasimov D.A. Modern employment in the digital economy Improving the methodological framework for the introduction of forms. Economics Doctor of Science (DSc) Dissertation Abstract, 2020

11. https://www.ilo.org/moscow/news/WCMS_741071/lang--en/index.htm

12. Asamxodjaeva Sh.Sh. The pandemic of human capital and its development effect // Scientific electronic journal "Finance and Banking", May 2, 2020. 193-198-pages. 